\title{
Association of Hepatitis C Virus Infection and Type 2 Diabetes in Egypt: A Hospital-Based Study
}

\author{
Shaimaa B. Abdelazizi ${ }^{*}$, Yasmine S. Galal' ${ }^{1}$, Amal S. Sedrak1, Dina S. Shaheen ${ }^{2}$ \\ ${ }^{1}$ Department of Public Health, Cairo University, Cairo, Egypt \\ ${ }^{2}$ Department of Internal Medicine, Cairo University, Cairo, Egypt \\ Email: "Shaimaabaher@yahoo.com,yasminegalal@hotmail.com,amal_newlife82@yahoo.com, \\ drshaheen@hotmail.com
}

Received 19 January 2016; accepted 23 February 2016; published 26 February 2016

Copyright @ 2016 by authors and Scientific Research Publishing Inc.

This work is licensed under the Creative Commons Attribution International License (CC BY).

http://creativecommons.org/licenses/by/4.0/

c. (i)

\section{Abstract}

Background: The relation between hepatitis $\mathrm{C}$ virus (HCV) infection and the development of type 2 diabetes mellitus (T2DM) remains unknown. The aim of this study was to investigate the presence of an association between T2DM and HCV. Methods: A case control study was conducted at the outpatients' clinics of Kasr El-Aini Hospital (KAH), from October 2013 till March 2014. In this study, 389 HCV patients were selected as cases and 389 healthy controls were also included. Demographic and clinical data were collected using a structured questionnaire. Laboratory investigations including liver function tests (LFT), blood glucose level and radioimmunoblot assay (ELISA) were performed. Results: Out of 389 HCV cases, 219 (56.3\%) were diabetic, whereas 145 (37.3\%) were diabetic among the healthy controls. Occurrence of diabetes among cirrhotic patients was 1.7 times higher than non-cirrhotic. Logistic regression showed that residence $(P<0.001,0 R=2.7)$, occupation ( $P=0.03,0 R=1.8)$, and smoking $(P=0.04,0 R=2)$ were the predictive factors for occurrence of T2DM in HCV patients. Conclusions: In this study, we found a positive association between HCV infection and T2DM. Residence, occupation and smoking were the predictive factors for the association of T2DM in HCV patients, whereas hypertension and BMI were only adjunctive factors.

\section{Keywords}

HCV, Predictive Factors, T2DM, Cirrhosis

\footnotetext{
"Corresponding author.
} 


\section{Introduction}

Hepatitis C Virus (HCV) infection is a major public health problem, which currently affects over 200 million people, with an estimated prevalence of $2.2 \%$ globally [1]. Egypt has the highest prevalence rate of HCV in the world, making it the most challenging health problem facing the country. Studies show that $14.7 \%$ of the Egyptian population carry HCV antibodies [2] and 9.8\% have an active infection [3].

The wave of increased HCV-related morbidity and mortality is likely due to the widespread availability of injectable therapies and the illicit use of injectable drugs [4]. Currently the association between HCV infection and T2DM had been reported in a number of clinical studies though conflicting results were reported [5] [6].

Both diabetes and HCV infection are severe health problems worldwide, especially in the developing countries [7] [8]. A range of extra-hepatic manifestations such as arthralgia, thyroiditis and diabetes are linked with HCV infections [9]. Studies have shown that patients infected with HCV have more glucose intolerance than the general population [10] [11].

The mechanism of pathogenesis of diabetes in patients with HCV infection remains unclear though it has been implicated that insulin resistance plays an important role and is related to fibrosis score [12].

T2DM is a major public health problem worldwide that is rapidly emerging due to increasing prevalence of obesity and sedentary lifestyle [8]. Aging, obesity, family history of diabetes, and Human Immunodeficiency Virus (HIV) co-infection are recognized influencing factors associated with diabetes development among HCVinfected patients [13].

Several studies from different parts of the world have found that $13 \%$ to $33 \%$ of patients with chronic HCV have associated diabetes, mostly T2DM [14] [15]. In Egypt, some studies have reported that the prevalence of T2DM among HCV patients is $25.4 \%$ [16] and that chronic HCV patients are three times more likely to develop T2DM than HCV seronegative patients [17]. Therefore, it is important to identify the magnitude of the problem of DM in order to optimize the cost and reduce failure of treatment in HCV patients who are at risk to develop T2DM.

The aim of this study was to elucidate the presence of association between HCV and T2DM and explore the factors that might be predicting the occurrence of DM in patients with HCV considering other known possible DM risk factors. Furthermore, the study is invented to provide valuable insight regarding usefulness of focused screening program in HCV to improve patients' outcome and quality of services.

\section{Patients and Methods}

\subsection{Study Design, Period and Setting}

A nested case-control study was conducted from October 2013 till March 2014, at the Tropical Medicine and Gastroenterology outpatients' clinics of KAH, Cairo University. It is one of the largest tertiary care academic teaching hospitals in the region. At the present time, it has 36 departments, 42 specialized units, 5200 beds over 9 hospitals which serve approximately 2 million patients a year.

\subsection{Study Participants}

Only HCV patients who were older than 18 years and had their antibody profile positive for HCV, were included as cases. Patients with decompensated liver disease, cancer, on interferon therapy, autoimmune disease, having end stage renal disease or coexisting viral infection like hepatitis B surface antigen positive patients, pregnant females were excluded from the research. Controls were recruited from the cardiology and chest outpatient clinics of KAH with normal liver function tests, no serological evidence of HCV and no recent illness.

The sample size was estimated by using the statistical software program Epicalc 2000 [18]. The minimum required sample size was 778 subjects (389 HCV-positive cases and 389 HCV-negative controls) based on an alpha error (type I error) of 5\%, $80 \%$ statistical power and an accepted error of $2 \%$. All the participants were recruited from the selected clinics by using a systematic random sampling technique whereas every $3^{\text {rd }}$ patient was interviewed.

\subsection{Data Collection and Laboratory Methods}

Data were collected using a structured questionnaire containing questions related to demographic, clinical cha- 
racteristics and nutritional status of patients [17].

HCV infection was diagnosed if patients were seropositive for anti-HCV, and conformational testing was performed by ELISA if the diagnosis was in doubt. A laboratory technician aseptically collected $3-5 \mathrm{~mL}$ of venous blood by using plain vacutainer tube for the detection of the anti-HCV antibodies and level of liver enzymes, $3 \mathrm{ml}$ blood sample in the plain tube were centrifuged at 3000 RPM for 5 minutes to separate the serum and some of it were used for determination of level liver enzymes: Aspartate transaminase (AST), Alanine transaminase (ALT) within one hour of separation. The remaining serum was kept in deep freezer at $\left(-20^{\circ} \mathrm{C}\right)$ until detection of anti-HCV antibodies. All samples were sent to the lab at the clinical pathology department, Cairo University Hospitals for diagnosis. Abdominal ultrasonography was done for serological HCV-positive patients to diagnose liver cirrhosis.

To investigate diabetes the remaining $2 \mathrm{ml}$ of venous blood was drawn in EDTA-supplied test tubes and samples were sent to the lab for investigation. Defining T2DM was done according to the American Diabetes Association guidelines (2008) [19]. Patients were assigned a diagnosis of DM if there was a documented use of oral hypoglycemic medication or insulin; poor glycemic control (random blood sugar $\geq 200 \mathrm{mg} / \mathrm{dL}$ ).

Patients who had corticosteroid-induced diabetes were excluded. From each HCV antibody-positive diabetic patient, the researchers reviewed the date of diagnosis of DM, type of DM and dates of possible exposure to HCV infection or onset of hepatitis when known. Uncontrolled or newly diagnosed diabetic patients were sent to the specialist clinic for further medical care and follow up.

Assessment of the nutritional status was done for the study participants by measuring body weight and height. After recording the measurements, patients were classified according to their body mass index (BMI) into: underweight $\left(<18.5 \mathrm{~kg} / \mathrm{m}^{2}\right)$, normal $\left(18.5-24.99 \mathrm{~kg} / \mathrm{m}^{2}\right)$, overweight $\left(25-29.99 \mathrm{~kg} / \mathrm{m}^{2}\right)$ and obese $\left(\geq 30 \mathrm{~kg} / \mathrm{m}^{2}\right)$ [20].

\section{Statistical Analysis}

Data analysis was carried out using SPSS software for Windows, version 21 Statistical Package of Social Sciences (SPSS Inc., Chicago, IL) [21]. Descriptive analysis was performed and the results were expressed as mean \pm SD and percentages. Comparison between groups (cases and controls) was done using the Student's $t$ test for continuous variables and Pearson chi-square test for nominal categorical variables. Logistic regression analysis was used to evaluate the predictive variables that could be associated with the presence of diabetes. Odds ratio (OR) and their respective $95 \%$ confidence intervals (CI) were calculated. P value of $\leq 0.05$ was considered statistically significant.

\section{Ethical Considerations}

After explaining the purpose of the study, a written informed consent was taken from the participants before collecting data and taking samples. The current research was approved by the ethics committee of the KAH and was conducted in accordance with Helsinki declaration [22].

\section{Results}

In this study, a total of 778 participants (389 HCV cases and 389 non HCV controls) were included. Out of this total, DM was found in 364 patients; 219 (56.3\%) HCV cases and 145 (37.3\%) non HCV controls, 342 patients were aware of their problem, whereas 22 cases were newly diagnosed. There was a two fold increase in the percentage of diabetes among HCV cases as compared to non HCV controls [Figure 1], and the mean duration of diabetes among known diabetic patients was $(7.41 \pm 3.82)$ years.

\subsection{HCV Cases Diabetics and Non Diabetics}

Out of 389 HCV cases, DM was found in219 (56.3\%), among which only 63 (28.8\%) were controlled diabetic cases (good glycemic control), 139 (63.4\%) were uncontrolled (poor glycemic control), and 17 (7.8\%) were newly diagnosed (random blood sugar $\geq 200 \mathrm{mg} / \mathrm{dl}$ ). Table 1 show that the majority cases were older than forty years and were females. The mean duration of hepatic illness among HCV diabetic cases (15.55 \pm 8.81 years) was significantly higher $(\mathrm{P}=0.01)$ than that of $\mathrm{HCV}$ non diabetics $(12.76 \pm 6.34$ years $)$. There was a significant association between cirrhosis and diabetes in HCV patients $(\mathrm{P}=0.001)$. 
Table 1. Sociodemograhic and clinical characteristics of diabetic and non-diabetic HCV cases.

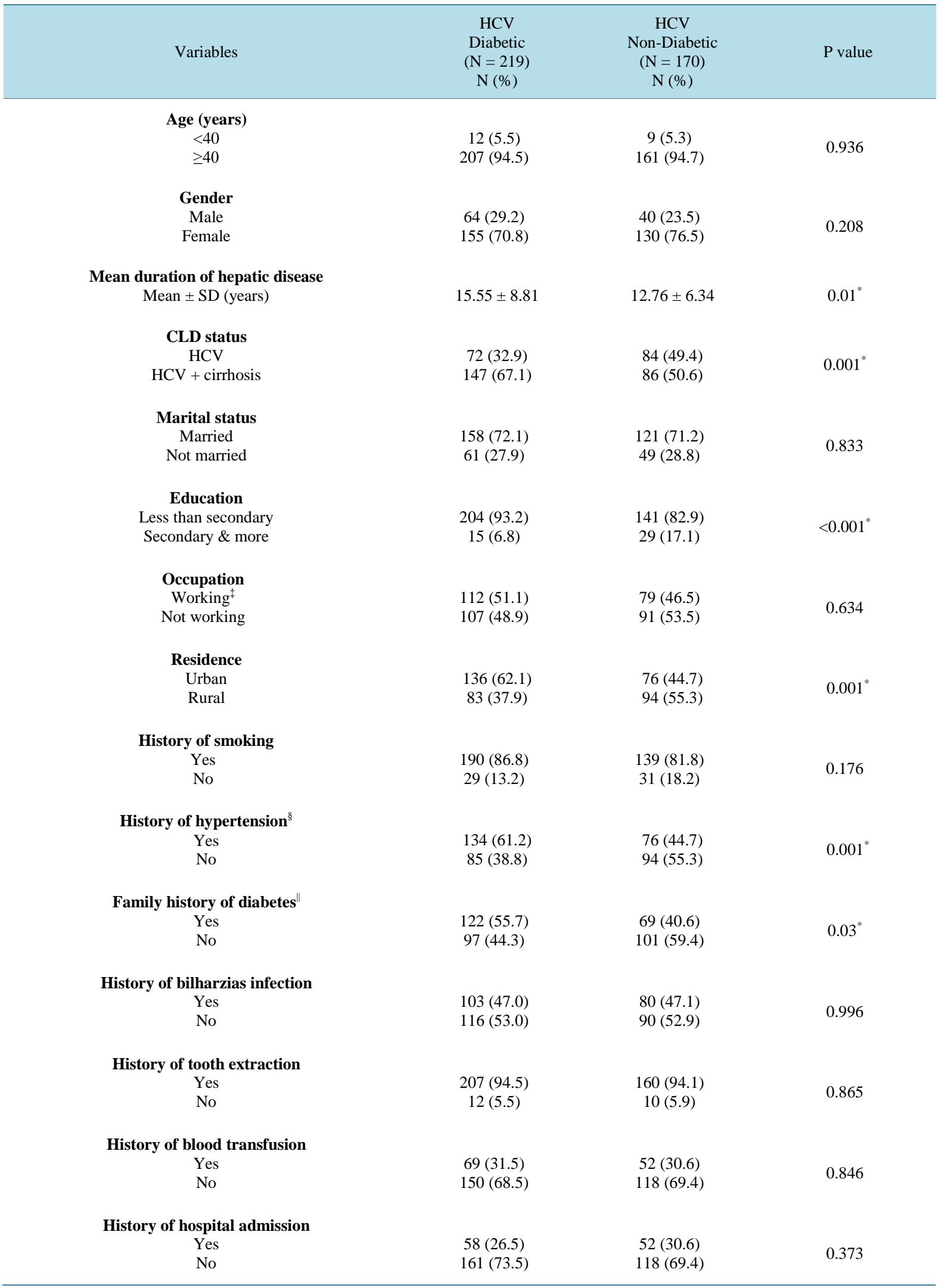




\section{Continued}

History of injection (IV/IM)
Yes

Yes

No

BMI $\left(\mathbf{k g} / \mathrm{m}^{2}\right)$

Normal $(<25)$

Overweight/obese( $>25)$

AST (U/L)
Normal $(<40)$
Elevated $(>40)$

$\operatorname{ALT}(\mathrm{U} / \mathrm{L})$

Normal $(<40)$

Elevated $(>40)$

Cholesterol level $^{\dagger}$ (mg/dl)

Normal $(<200)$

Elevated $(>200)$
36 (16.4)

183 (83.6)

87 (39.7)

132 (60.3)

68 (31.1)

151 (68.9)

79 (36.1)

140 (63.9)

23 (71.9)

9 (28.1)
31 (18.2)

139 (81.8)

0.09

51 (30.0)

119 (70.0)

$0.04^{*}$

69 (40.6)

101 (59.4)

$0.05^{*}$

76 (44.7)

94 (55.3)

0.08

19 (100.0)

$0(0.0)$

$0.01^{*}$

CLD: chronic liver disease status, BMI: body mass index, IV: intra-venous, IM: intra-muscular, AST: aspartate transaminase, ALT: alanine transaminase; ${ }^{*}$ Statistically significant value $<0.05 ;{ }^{\dagger}$ Total cases $=32$, controls $=19 ;{ }^{~}{ }^{\ddagger}$ Workers include: farmer, builder, industrial, trade workers; ${ }^{\S}$ Includes patients who require special diet or antihypertensive agents; "Indicates presence of at least one first-degree relative affected by DM.

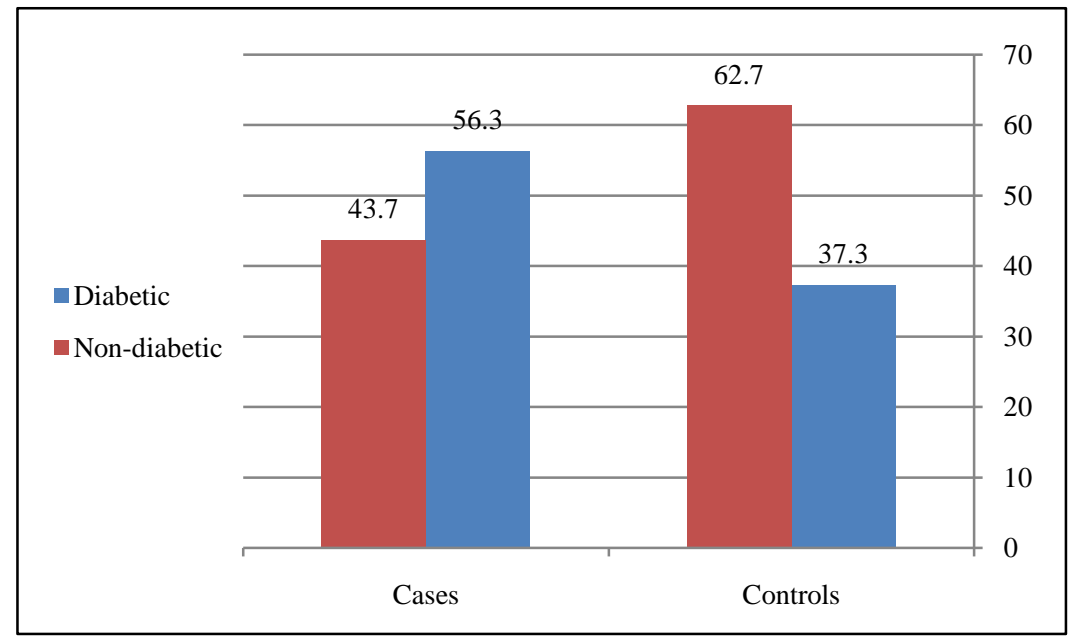

$(\mathrm{P}<0.001)$

Figure 1. Diabetes among HCV cases in comparison to non HCV controls.

Bivariate analysis was used to compare some risk factors between diabetic and non-diabetic HCV patients [Table 1]. The occurrence of DM was significantly associated with level of education $(\mathrm{P}<0.001)$, residence $(\mathrm{P}$ $=0.001)$, history of hypertension $(\mathrm{P}=0.001)$, family history of DM $(\mathrm{P}=0.03)$, and higher $\mathrm{BMI}(\mathrm{P}=0.04)$. Significantly higher AST and cholesterol levels were detected among HCV diabetic cases compared with non diabetics. As regards HCV risk factors which include: history of bilharzia infection, tooth extraction, blood transfusion, hospital admission, history of injection; none of these risk factors were significantly associated with HCV in both diabetic and non-diabetic patients $(\mathrm{P}>0.05)$ [Table 1 ].

The binary logistic regression model was used to detect the predictive variables for occurrence of DM among HCV patients. Residence $(\mathrm{P}=0.005$, $\mathrm{OR}=1.8,95 \% \mathrm{CI}: 1.20-2.95)$, history of hypertension $(\mathrm{P}=0.01, \mathrm{OR}=$ 1.6, 95\%CI: 1.09 - 2.62) and family history of diabetes $(\mathrm{P}=0.01$, OR $=1.7,95 \% \mathrm{CI}: 1.14-2.74)$ were found to be independently associated with DM (OR > 1) [Table 2]. The occurrence of T2DM in HCV cirrhotic patients was 1.7 times higher as compared with non-cirrhotic patients $(\mathrm{P}=0.02$, $\mathrm{OR}=1.7,95 \% \mathrm{CI}$ : 1.08 - 2.69). 
Table 2. Logistic regression for significant variables predicting the occurrence of diabetes among HCV cases.

\begin{tabular}{|c|c|c|c|c|}
\hline Risk factors & OR & Lower & Upper & $P$ value \\
\hline $\begin{array}{c}\text { Education } \\
\text { Secondary \& more } \\
\text { Less than secondary }\end{array}$ & $\begin{array}{c}1 \\
0.3\end{array}$ & 0.17 & 0.70 & $0.003^{*}$ \\
\hline $\begin{array}{l}\text { Residence } \\
\text { Rural } \\
\text { Urban }\end{array}$ & $\begin{array}{c}1 \\
1.8\end{array}$ & 1.20 & 2.95 & $0.005^{*}$ \\
\hline $\begin{array}{c}\text { History of hypertension } \\
\text { No } \\
\text { Yes }\end{array}$ & $\begin{array}{c}1 \\
1.6\end{array}$ & 1.09 & 2.62 & $0.01^{*}$ \\
\hline $\begin{array}{c}\text { Family history of diabete } \\
\text { No } \\
\text { Yes }\end{array}$ & $\begin{array}{c}1 \\
1.7\end{array}$ & 1.14 & 2.74 & $0.01^{*}$ \\
\hline $\begin{array}{l}\text { CLD } \\
\text { Chronic hepatitis } \\
\text { Cirrhosis }\end{array}$ & $\begin{array}{c}1 \\
1.7\end{array}$ & 1.08 & 2.69 & $0.02^{*}$ \\
\hline $\begin{array}{c}\text { BMI }\left(\mathbf{k g} / \mathbf{m}^{2}\right) \\
\text { Normal }(<25) \\
\text { Overweight/obese }(\geq 25)\end{array}$ & $\begin{array}{c}1 \\
0.5\end{array}$ & 0.35 & 0.895 & $0.01^{*}$ \\
\hline
\end{tabular}

$\mathrm{R}=0.118 ; \mathrm{P}<0.001$; *Statistically significant value $<0.05$; OR: Odds ratio, CI: Confidence interval.

\subsection{HCV Controls Diabetics and Non Diabetics}

Out of 389 HCV controls, DM was found in 145 (37.3\%), among which 49 (33.8\%) were controlled diabetics (good glycemic control), 91 (62.8\%) were uncontrolled (poor glycemic control) and 5 (3.4\%) were newly diagnosed patients (random blood glucose $\geq 200 \mathrm{mg} / \mathrm{dl}$ ). Table 3 shows that age distribution, gender, marital status, family history of DM, and BMI differed significantly among non HCV controls regarding their diabetic state. Also in non HCV controls, diabetic subjects had significantly higher AST and ALT levels.

\subsection{HCV Diabetics and Non HCV Diabetics}

Out of 364 diabetic patients, 112 (30.8\%) patients were controlled diabetic sand 252 (69.2\%) patients had random blood sugar $>200 \mathrm{mg} / \mathrm{dl}$. In Table 4, comparison between diabetic HCV cases and non HCV controls revealed that: more cases were older than forty years (62.9\% vs. 37.1\%); females (54.2\% vs. $45.8 \%)$; married (61\% vs. $39 \%)$; had lower level of education (59.1\% vs. $40.5 \%)$; working (67.5\% vs. $32.5 \%)$ from urban localities (72.7\% vs. $27.3 \%$ ) and had family history of diabetes (57.5\% vs. $42.5 \%)$. The difference between diabetic cases and controls was statistically significant regarding the former parameters except for the marital status, education and family history of diabetes.

A significantly higher proportion of diabetic HCV cases were smokers (62.7\% vs. $37.3 \%)$ and hypertensive (55.8\% vs. $44.2 \%$ ) in comparison to diabetic non HCV controls ( $\mathrm{P}<0.05)$. As for their nutritional status, it was indicated that subjects with BMI of $\geq 25 \mathrm{Kg} / \mathrm{m}^{2}(68.7 \%)$ had a significantly higher chance $(\mathrm{P}<0.001)$ to become diabetic as compared with normal BMI. Regarding abnormal lab characteristics, diabetic HCV cases had significantly higher AST (68.9\% vs. 31.1\%) and ALT levels (74.9\% vs. 25.1\%) than diabetic non HCV controls (P < 0.001).

After applying a logistic regression model, residence $(\mathrm{P}<0.001$, OR $=2.7,95 \% \mathrm{CI}$ : $1.61-4.70$ ), occupation $(\mathrm{P}=0.03$, OR $=1.8,95 \% \mathrm{CI}: 1.04-3.42)$, smoking $(\mathrm{P}=0.04, \mathrm{OR}=2.0,95 \% \mathrm{CI}: 1.00-4.26)$ were the predictive factors for occurrence of DM in patients with HCV [Table 5].

\section{Discussion}

There is a growing body of literature on the link between T2DM and HCV, however, studies are contradictory 
Table 3. Sociodemograhic and clinical characteristics of diabetic and non-diabetic HCV controls.

\begin{tabular}{|c|c|c|c|}
\hline Variables & $\begin{array}{c}\text { HCV controls } \\
\text { Diabetic } \\
(\mathrm{N}=145) \\
\mathrm{N}(\%)\end{array}$ & $\begin{array}{l}\text { HCV controls } \\
\text { Non-Diabetic } \\
(\mathrm{N}=244) \\
\mathrm{N}(\%)\end{array}$ & $P$ value \\
\hline \multicolumn{4}{|l|}{ Age (years) } \\
\hline$<40$ & 23 (15.9) & $111(45.5)$ & \multirow{2}{*}{$<0.001$} \\
\hline$\geq 40$ & $122(84.1)$ & $133(54.5)$ & \\
\hline \multicolumn{4}{|l|}{ Gender } \\
\hline Male & $14(9.7)$ & $51(20.9)$ & \multirow{2}{*}{$0.004^{*}$} \\
\hline Female & $131(90.3)$ & $193(79.1)$ & \\
\hline \multicolumn{4}{|l|}{ Marital status } \\
\hline Married & $101(69.7)$ & $201(82.4)$ & \multirow{2}{*}{$0.004^{*}$} \\
\hline Not married & $44(30.3)$ & $43(17.6)$ & \\
\hline \multicolumn{4}{|l|}{ Education } \\
\hline Less than secondary & 139 (95.9) & $227(93.0)$ & \multirow{2}{*}{0.253} \\
\hline Secondary \& more & $6(4.1 \%)$ & $17(7.0 \%)$ & \\
\hline \multicolumn{4}{|l|}{ Occupation } \\
\hline Working & $54(37.2)$ & 82 (33.5) & \multirow{2}{*}{0.497} \\
\hline Not working & 91 (62.8) & $162(66.5)$ & \\
\hline \multicolumn{4}{|l|}{ Residence } \\
\hline Urban & $51(35.2)$ & $67(27.5)$ & \multirow{2}{*}{0.111} \\
\hline Rural & $94(64.8)$ & $177(72.5)$ & \\
\hline \multicolumn{4}{|l|}{ History of smoking } \\
\hline Yes & 113 (77.9) & $184(75.4)$ & \multirow{2}{*}{0.572} \\
\hline No & $32(22.1)$ & $60(24.6)$ & \\
\hline \multicolumn{4}{|l|}{ History of hypertension } \\
\hline Yes & $106(73.1)$ & $161(66.0)$ & \multirow{2}{*}{0.143} \\
\hline No & 39 (26.9) & $83(34.0)$ & \\
\hline \multicolumn{4}{|l|}{ Family history of diabetes } \\
\hline Yes & $90(62.1)$ & $91(37.3)$ & \multirow{2}{*}{$<0.001^{*}$} \\
\hline No & 55 (37.9) & $153(62.7)$ & \\
\hline \multicolumn{4}{|l|}{ BMI $\left(\mathrm{kg} / \mathrm{m}^{2}\right)$} \\
\hline Normal $(<25)$ & $27(18.6)$ & $84(34.4)$ & \multirow{2}{*}{$0.001^{*}$} \\
\hline Overweight/obese $(\geq 25)$ & $118(81.4)$ & $160(65.6)$ & \\
\hline \multicolumn{4}{|l|}{ AST (U/L) } \\
\hline Normal $(<40)$ & $77(53.1)$ & 194 (79.5) & \multirow{2}{*}{$0.001^{*}$} \\
\hline Elevated $(\geq 40)$ & $68(46.9)$ & $50(20.5)$ & \\
\hline \multicolumn{4}{|l|}{$\operatorname{ALT}(\mathbf{U} / \mathbf{L})$} \\
\hline Normal $(<40)$ & $98(67.6)$ & 211 (86.5) & \multirow{2}{*}{$<0.001^{*}$} \\
\hline Elevated $(\geq 40)$ & $47(32.4)$ & $33(13.5)$ & \\
\hline \multicolumn{4}{|l|}{ Cholesterol level $^{\dagger}$ (mg/dl) } \\
\hline Normal $(<200)$ & $31(86.1)$ & $11(68.7)$ & \multirow{2}{*}{0.143} \\
\hline Elevated $(\geq 200)$ & 5 (13.9) & 5 (31.3) & \\
\hline
\end{tabular}

${ }^{*}$ Statistically significant value $<0.05 ;{ }^{\dagger}$ Total cases $=36$, controls $=16$. 
Table 4. Sociodemograhic and clinical characteristics of diabetic HCV cases and non HCV controls.

\begin{tabular}{|c|c|c|c|c|}
\hline Variables & $\begin{array}{l}\text { Diabetic } \\
\text { HCV cases } \\
\text { N (\%) }\end{array}$ & $\begin{array}{c}\text { Diabetic } \\
\text { Non HCV controls } \\
\text { N (\%) }\end{array}$ & $\begin{array}{c}\text { Total } \\
(\mathrm{N}=364)\end{array}$ & $P$ value \\
\hline \multicolumn{5}{|l|}{ Age (years) } \\
\hline$<40$ & $12(34.3)$ & $23(65.7)$ & $35(9.6)$ & \multirow{2}{*}{$0.001^{*}$} \\
\hline$\geq 40$ & $207(62.9)$ & $122(37.1)$ & $329(90.4)$ & \\
\hline \multicolumn{5}{|l|}{ Gender } \\
\hline Male & $64(82.1)$ & $14(17.9)$ & 78 (21.4) & \multirow{2}{*}{$<0.001^{*}$} \\
\hline Female & $155(54.2)$ & $131(45.8)$ & $286(78.6)$ & \\
\hline \multicolumn{5}{|l|}{ Marital status } \\
\hline Married & $158(61.0)$ & $101(39.0)$ & $259(71.2)$ & \multirow{2}{*}{0.608} \\
\hline Not married & $61(58.1)$ & $44(41.9)$ & 105 (28.8) & \\
\hline \multicolumn{5}{|l|}{ Education } \\
\hline Less than secondary & 204 (59.5) & 139 (40.5) & $343(94.2)$ & \multirow{2}{*}{0.277} \\
\hline Secondary \& more & $15(71.4)$ & $6(28.6)$ & $21(5.8)$ & \\
\hline \multicolumn{5}{|l|}{ Occupation } \\
\hline Working & $112(67.5)$ & $54(32.5)$ & $166(45.6)$ & \multirow{2}{*}{$<0.001$} \\
\hline Not working & $107(54.0)$ & $91(46.0)$ & $198(54.4)$ & \\
\hline \multicolumn{5}{|l|}{ Residence } \\
\hline Urban & 136(72.7) & $51(27.3)$ & $187(51.4)$ & \multirow{2}{*}{$<0.001^{*}$} \\
\hline Rural & $83(46.9)$ & $94(53.1)$ & $177(48.6)$ & \\
\hline \multicolumn{5}{|l|}{ History of smoking } \\
\hline Yes & $190(62.7)$ & $113(37.3)$ & $303(83.2)$ & \multirow{2}{*}{$0.02^{*}$} \\
\hline No & $29(47.5)$ & $32(52.5)$ & $61(16.8)$ & \\
\hline \multicolumn{5}{|l|}{ History of hypertension } \\
\hline Yes & $134(55.8)$ & $106(44.2)$ & $240(65.9)$ & \multirow{2}{*}{$0.01^{*}$} \\
\hline No & $85(68.5)$ & 39 (31.5) & $124(34.1)$ & \\
\hline \multicolumn{5}{|l|}{ Family history of diabetes } \\
\hline Yes & $122(57.5)$ & $90(42.5)$ & $212(58.2)$ & \multirow{2}{*}{0.228} \\
\hline No & $97(63.8)$ & $55(36.2)$ & $152(41.8)$ & \\
\hline \multicolumn{5}{|l|}{ BMI kg/m² } \\
\hline Normal $(<25)$ & 87 (76.3) & $27(23.7)$ & $114(31.3)$ & \multirow{2}{*}{$<0.001^{*}$} \\
\hline Overweight/obese ( $\geq 25$ ) & $132(52.8)$ & $118(47.2)$ & $250(68.7)$ & \\
\hline \multicolumn{5}{|l|}{ AST (U/L) } \\
\hline Normal $(<40)$ & 68 (46.9) & 77 (53.1) & 145 (39.8) & \multirow{2}{*}{$<0.001^{*}$} \\
\hline Elevated $(\geq 40)$ & $151(68.9)$ & $68(31.1)$ & $219(60.2)$ & \\
\hline \multicolumn{5}{|l|}{ ALT (U/L) } \\
\hline Normal $(<40)$ & 79 (44.6) & $98(55.4)$ & $177(48.6)$ & \multirow{2}{*}{$<0.001^{*}$} \\
\hline Elevated $(\geq 40)$ & $140(74.9)$ & $47(25.1)$ & $187(51.4)$ & \\
\hline \multicolumn{5}{|l|}{ Cholesterol level $^{\dagger}$ (mg/dl) } \\
\hline Normal $(<200)$ & $23(42.6)$ & $31(57.4)$ & $54(79.4)$ & 0.147 \\
\hline Elevated $(\geq 200)$ & $9(64.3)$ & $5(35.7)$ & $14(20.6)$ & \\
\hline Glycemic control (mg/dl) & & & & \\
\hline Good $(<200)$ & $63(56.3)$ & 49 (43.7) & $112(69.2)$ & \\
\hline $\operatorname{Bad}(\geq 200)$ & $156(61.9)$ & $96(38.1)$ & $252(30.8)$ & 0.309 \\
\hline
\end{tabular}

${ }^{*}$ Statistically significant value $<0.05 ;{ }^{\dagger}$ Total cases $=32$, controls $=36$. 
Table 5. Logistic regression analysis of factors associated with DM among HCV cases and controls.

\begin{tabular}{|c|c|c|c|c|}
\hline Risk factors & OR & Lower & Upper & Sig \\
\hline \multicolumn{5}{|l|}{ Age } \\
\hline$<40$ years & 1 & \multirow{2}{*}{0.77} & \multirow{2}{*}{3.99} & \multirow{2}{*}{0.180} \\
\hline$\geq 40$ years & 1.7 & & & \\
\hline \multicolumn{5}{|l|}{ Gender } \\
\hline Male & 1 & \multirow{2}{*}{0.30} & \multirow{2}{*}{1.45} & \multirow{2}{*}{0.309} \\
\hline Female & 0.6 & & & \\
\hline \multicolumn{5}{|l|}{ Residence } \\
\hline Rural & 1 & \multirow{2}{*}{1.61} & \multirow{2}{*}{4.70} & \multirow{2}{*}{$<0.001^{*}$} \\
\hline Urban & 2.7 & & & \\
\hline \multicolumn{5}{|l|}{ Occupation } \\
\hline Not working & 1 & \multirow{2}{*}{1.04} & \multirow{2}{*}{3.42} & \multirow{2}{*}{$0.03^{*}$} \\
\hline Working ${ }^{\times}$ & 1.8 & & & \\
\hline \multicolumn{5}{|l|}{ History of smoking } \\
\hline No & 1 & \multirow{2}{*}{1.00} & \multirow{2}{*}{4.26} & \multirow{2}{*}{$0.04^{*}$} \\
\hline Yes & 2.0 & & & \\
\hline \multicolumn{5}{|l|}{ History of hypertension } \\
\hline No & 1 & \multirow{2}{*}{0.28} & \multirow{2}{*}{1.15} & \multirow{2}{*}{0.118} \\
\hline Yes & 0.5 & & & \\
\hline \multicolumn{5}{|l|}{ BMI kg/m² } \\
\hline $\begin{array}{c}\text { Normal }(<25) \\
\text { Oyerweight/obese }(>25)\end{array}$ & 1 & 0.32 & 1.15 & 0.131 \\
\hline
\end{tabular}

$\mathrm{R}=0.238 ; \mathrm{P}<0.001$; ${ }^{*}$ Statistically significant value $<0.05$; OR: Odds ratio, CI: Confidence interval.

and the data is inconclusive [23] [24]. Recent data had suggested that the prevalence of T2DM in HCV seropositive patients is three times higher compared to non HCV controls [25]-[27]. The present study found a strong association between HCV and T2DM, however, 22 diabetic cases were unaware of their endocrinal problem before being screened. The later findings highlight the importance of periodical screening for HCV patients especially in advanced stages. In contrast, some studies provided evidence against a potential association between these two disorders [16] [28] [29].

In Egypt the estimated prevalence of overt DM in adult ranges from $10 \%$ to $20 \%$ [30], which is about 2 to 3 times less than what was found in this study (56.5\%), indicating that patients with HCV are a high-risk population for DM. This is in agreement with a previous study done in India [31] but in contrast with others [10] [32]. This contradiction may be attributed to differences in environmental factors, genetic susceptibility and diet.

Consistent with other previous studies [16] [27], HCV cirrhotic patients had a significantly higher prevalence of DM than non-cirrhotic patients. In contrast, Giordanino et al. 2008 [33] reported different findings. The discrepancies among studies may be explained by the degree of severity of liver disease. Expectedly, the current study revealed an independent association between cirrhosis and DM rate $(\mathrm{OR}=1.7)$. Similarly, studies from different areas [34] [35] proves that advancing liver disease increased susceptibility of HCV seropositive patients to develop T2DM.

Age is another definite risk factor for T2DM in the normal population [20]. In this study HCV diabetic cases were older than non HCV diabetic subjects, which is interestingly similar to the findings of other studies [36] [37] by supporting the idea that the occurrence of diabetes in HCV patients is progressive rather than abrupt [15]. Other studies suggest that HCV interferes with glucose metabolism independently of age. [21] [24] Therefore, screening for and prevention of diabetes in persons with HCV infection should be started earlier than the suggested age of $\geq 45$ years for the general population [28].

Diabetes as a disease affects both the male and female gender [38]. In this study, there were more female diabetic patients positive for anti-HCV antibodies than their male counter parts, which corroborates an earlier report by Huang et al. 2007 [39]. 
HCV patients with T2DM tended to have lower educational attainment in comparison to non diabetics [24]. The present study showed a significant association between educational level and HCV Ab seroprevalence (P < 0.001) and this agrees with the work done by Rajesh et al. 2012 [40]. High prevalence of HCV in illiterate people may be attributed to many factors such as paucity of health education programs about chronic viral hepatitis in educational systems and inaccurate estimates of the burden of disease.

In the present study, both bivariate and regression analysis showed that the occurrence of diabetes among HCV cases was independently related to occupation and residence, where most of the HCV cases were skilled workers and from urban localities in comparison to non HCV diabetic controls. This agrees with the work of Elhawary et al. 2011 [16] who observed the same findings.

Habitual smoking is a well-documented risk factor for exacerbation of liver conditions [41]. There was a history of cigarette smoking among $62.7 \%$ of HCV diabetic subjects in comparison to $37.3 \%$ of non HCV diabetic subjects. This finding is similar to that reported by Eissa et al. [42] but in contradiction with Alavian et al. [43] who noted lower figures.

Although DM was associated with hypertension in bivariate analysis, it lost its significance as a predictor of $\mathrm{DM}$ in the logistic regression model after adjustment for other related variables. It is currently believed that the presence of cardiovascular disease is rare in cirrhosis and that cirrhotic patients have a low prevalence of vascular disease including hypertension even in the presence of overt DM [44]. The current study supported this hypothesis showing no difference in the rate of hypertension between diabetic HCV cases and controls.

Family history of DM is a well-known risk factor for DM. The correlation between DM and HCV in this study remained significant even when family history of DM was entered through logistic regression model. When diabetes groups were analyzed separately among studied HCV patients, it was observed that patients with a positive family history of DM did not show an increased frequency of DM. Interestingly, this coincides with the work of Nadok et al. 2009 [45] who indicated that liver injury per se was associated with DM and that a family history of DM was only an adjunctive factor.

Overweight and obesity are major causes of fatty liver disease, insulin resistance, and T2DM [46]. Coexistence of HCV infection and overweight increases the risk of developing diabetes. In the current study, high BMI was one of the factors associated with the occurrence of diabetes among HCV cases, but it lost its significance in the logistic regression model. This finding shows that the diabetogenic effect of HCV infection is nearly similar to the effect of overweight and obesity [47]. This finding is important for public health and clinical practice because the prevalence of HCV infections endemic in some developing countries and high-risk groups in developed countries because of unsafe injections and intravenous drug use [41]. Therefore, it is particularly important for HCV-infected persons to change their lifestyle to control their body weight to prevent the development of diabetes.

In a study conducted by Harris (2005), individuals with T2DM had a higher incidence of liver function test (LFT) abnormalities than non diabetics [48], which is similar to the findings of this study. However, Chehadeh et al. [15] found no difference in this aspect. In present study, levels of liver enzymes and cholesterol in diabetics were higher in HCV cases compared with non-HCV controls, which may have therapeutic implications in the management of patients with HCV. It is necessary to emphasize weight control in overweight patients in order to decrease both the risk of DM and to prevent liver damage. Since the co-infection ofT2DM and HCV has been established to worsen each other, it is crucial to perform screening tests to determine the prevalence of T2DM among HCV patients.

In relation to glycemic control, it was noted that patients with bad glycemic control were at more at risk of having HCV infection as compared to those with good glycemic control, which goes in accordance with Jadoon et al. 2010 [49] who reported the same finding. This may be because of various confounding factors, which warrants further investigation. In this regard, screening for diabetes should be indicated in these patients.

The most important limitations in this study were: small sample size, hospital-based study and the difficulty of testing for HCV RNA in a teaching hospital like Cairo University due to the very high cost and limited facilities.

\section{Conclusion and Recommendations}

There is a significant association between HCV infection and T2DM. However, it remains unclear whether HCV infection is a risk factor for diabetes or vice versa. Development of T2DM increases by nearly two folds if an 
HCV patient has cirrhosis. Residence, occupation and smoking were the predictive factors for the association of T2DM in HCV patients, whereas hypertension and BMI were only adjunctive factors. Further studies regarding the association of the two conditions are needed to illustrate the relationship and improve management strategies. Limited resources for HCV prevention in Egypt necessitate that healthcare policy-makers should implement prevention strategies and infection control programs in healthcare settings to avoid the double burden of HCV and DM and to improve the overall quality of care.

\section{Acknowledgements}

We acknowledge the Internal Medicine and Clinical Pathology Departments, Faculty of Medicine, Cairo University. The authors would like also to thank all nurses who helped in collecting the samples. The research team thanks all patients for their co-operation.

\section{References}

[1] Bostan, N. and Mahmood, T. (2010) An Overview about Hepatitis C: A Devastating Virus. Critical Reviews in Microbiology, 36, 91-133. http://dx.doi.org/10.3109/10408410903357455

[2] Esmat, G. (2013) Hepatitis C in the Eastern Mediterranean Region. Eastern Mediterranean Health Journal, 19, 587588.

[3] El-Zanaty, F. and Way, A. (2009) Egypt Demographic and Health Survey 2008. Ministry of Health, El-Zanaty and Associates, and Macro International, Cairo.

[4] (2004) Global Burden of Disease (GBD) for Hepatitis C. Journal of Clinical Pharmacology, 44, 20-29. http://dx.doi.org/10.1177/0091270003258669

[5] Alter, M.J. (2007) Epidemiology of Hepatitis C Virus Infection. World Journal of Gastroenterology, 13, 2436. http://dx.doi.org/10.3748/wjg.v13.i17.2436

[6] Lecube, A., Hernandez, C., Genesca, J. and Esteban, J. (2004) Diabetes Is the Main Factor Accounting for the High Ferritin Levels Detected in Chronic HCV Infection. Diabetes Care, 27, 2669-2675. http://dx.doi.org/10.2337/diacare.27.11.2669

[7] Negro, F. and Alaei, M. (2009) Hepatitis C Virus and Type 2 Diabetes. World Journal of Gastroenterology, 15, 15371547. http://dx.doi.org/10.3748/wjg.15.1537

[8] Waheed, Y., Safi, S.Z. and Qadri, I. (2011) Role of Potash Alum in Hepatitis C Virus Transmission at Barber's Shop. Virology Journal, 8, 211. http://dx.doi.org/10.1186/1743-422X-8-211

[9] Safi, S.Z., Qvist, R., Kumar, S., Batumalaie, K. and Ismail, I.S. (2014) Molecular Mechanisms of Diabetic Retinopathy, General Preventive Strategies, and Novel Therapeutic Targets. BioMed Research International, 2014, Article ID: 801269. http://dx.doi.org/10.1155/2014/801269

[10] Mehta, S.H., Brancati, F.L., Sulkowski, M.S., Strathdee, S.A., Szklo, M. and Thomas, D.L. (2000) Prevalence of Type 2 Diabetes Mellitus among Persons with Hepatitis C Virus Infection in the United States. Annals of Internal Medicine, 133, 592-599. http://dx.doi.org/10.7326/0003-4819-133-8-200010170-00009

[11] Antonelli, A., Ferri, C., Fallahi, P., Ferrari, S.M., Ghinoi, A., Rotondi, M., et al. (2006) Thyroid Disorders in Chronic Hepatitis C Virus Infection. Thyroid, 16, 563-572. http://dx.doi.org/10.1089/thy.2006.16.563

[12] Sanzone, A.M. and Begue, R.E. (2006) Hepatitis C and Arthritis: An Update. Infectious Disease Clinics of North America, 20, 877-889. http://dx.doi.org/10.1016/j.idc.2006.09.010

[13] Chen, L.K., Hwang, S.J., Tsai, S.T., Luo, J.C., Lee, S.D. and Chang, F.Y. (2003) Glucose Intolerance in Chinese Patients with Chronic Hepatitis C. World Journal of Gastroenterology, 9, 505-508. http://dx.doi.org/10.3748/wjg.v9.i3.505

[14] Wilson, C. (2004) Hepatitis C Infection and Type 2 Diabetes in American-Indian Women. Diabetes Care, 27, 21162719. http://dx.doi.org/10.2337/diacare.27.9.2116

[15] Mohamoud, Y., Mumtaz, G., Riome, S., Miller, D. and Abu-Raddad, L. (2013) The Epidemiology of Hepatitis C Virus in Egypt: A Systematic Review and Data Synthesis. BMC Infectious Diseases, 13, 288. http://dx.doi.org/10.1186/1471-2334-13-288

[16] Chehadeh, W., Abdella, N., Ben-Nakhi, A., Al-Arouj, M. and Al-Nakib, W. (2009) Risk Factors for the Development of Diabetes Mellitus in Chronic Hepatitis C Virus Genotype 4 Infection. Journal of Gastroenterology, 24, 42-48. http://dx.doi.org/10.1111/j.1440-1746.2008.05503.x

[17] Elhawary, E.I., Mahmoud, G.F., El-Daly, M.A., Mekky, F.A., Esmat, G.G. and Abdel-Hamid, M. (2011) Association of HCV with Diabetes Mellitus: An Egyptian Case-Control Study. Virology Journal, 8, 367-377. 
[18] Corsini, A. (2009) Free Statistics. Free Statistical Software Comparisons. http://en.freestatistics.info/comp.php

[19] American Diabetes Association (ADA) (2008) Diagnosis and Classification of Diabetes Mellitus. Diabetes Care, 31, S55-S60.

[20] World Health Organization (WHO) (2000) Obesity: Preventing and Managing the Global Epidemic. Report of a WHO Consultation. Technical Report Series No. 894, World Health Organization, Geneva. http://www. who.int/nutrition/publications/obesity/WHO_TRS_894/en/

[21] Levesque, R. (2007) SPSS Programming and Data Management. A Guide for SPSS and SAS Users. 4th Edition, SPSS Inc., Chicago.

[22] Medical Association Declaration of Helsinki-Ethical Principles for Medical Research Involving Human Subjects. http://www.wma.net/en/30publications/10policies/b3/index.html

[23] Gulcan, A., Gulcan, E., Toker, A., Bulut, I. and Akcan, Y. (2008) Evaluation of Risk Factors and Seroprevalence of Hepatitis B and C in Diabetic Patients in Kutahya, Turkey. Journal of Investigative Medicine, 56, 858-863.

[24] Costa, L.M., Mussi, A.D., Brianeze, M.R. and Souto, F.J. (2008) Hepatitis C as a Risk Factor for Diabetes Type 2: Lack of Evidence in a Hospital in Central-West Brazil. Brazilian Journal of Infectious Diseases, 12, 24-26. http://dx.doi.org/10.1590/S1413-86702008000100007

[25] Kaabia, N., Ben Jazia, E., Slim, I., Fodha, I., Hachfi, W., Gaha, R., et al. (2009) Association of Hepatitis C Virus Infection and Diabetes in Central Tunisia. World Journal of Gastroenterology, 15, 2778-2781. http://dx.doi.org/10.3748/wjg.15.2778

[26] Ali, S., Abera, S., Mihret, A. and Abebe, T. (2012) Association of Hepatitis C Virus Infection with Type II Diabetes in Ethiopia: A Hospital-Based Case-Control Study. Interdisciplinary Perspectives on Infectious Diseases, 2012, Article ID: 354656. http://dx.doi.org/10.1155/2012/354656

[27] Sadik, M.M., Islam, A.Z., Naz, F., Zaki, M., Kumar, S. and Ali, B.A. (2013) Prevalence of Type 2 Diabetes Mellitus in Hepatitis C Virus Infected Population: A Southeast Asian Study Hindawi. Journal of Diabetes Research, 2013, Article ID: 539361. http://dx.doi.org/10.1155/2013/539361

[28] Wang, C.S., Wang, S.T., Yao, W.J., Chang, T.T. and Chou, P. (2007) Hepatitis C Virus Infection and the Development of Type 2 Diabetes in a Community-Based Longitudinal Study. American Journal of Epidemiology, 166, 196-203. http://dx.doi.org/10.1093/aje/kwm061

[29] Veldt, B.J., Chen, W., Heathcote, E.J., Wedemeyer, H., Reichen, J., Hofmann, W.P., et al. (2008) Increased Risk of Hepatocellular Carcinoma among Patients with Hepatitis C Cirrhosis and Diabetes Mellitus. Hepatology, 47, 18561862. http://dx.doi.org/10.1002/hep.22251

[30] Herman, W.H., Ali, M.A., Aubert, R.E., Engelgau, M.M., Kenny, S.J., Gunter, E.W., et al. (1995) Diabetes Mellitus in Egypt: Risk Factors and Prevalence. Diabetic Medicine, 12, 1126-1131. http://dx.doi.org/10.1111/j.1464-5491.1995.tb00432.x

[31] Sadikot, S.M., Nigam, A., Das, S., Bajaj, S., Zargar, A.H. and Sosale, A. (2004) The Burden of Diabetes and Impaired Glucose Tolerance in India Using the WHO 1999 Criteria; Prevalence of Diabetes in India Study (PODIS). Diabetes Research and Clinical Practice, 66, 301-307. http://dx.doi.org/10.1016/j.diabres.2004.04.008

[32] Zhao, P., Wang, J.B. and Jiao, J. (2006) Investigation on the Incidence of Diabetes in Chronic Hepatitis C Patients and Their HCV Genotypes. Chinese Journal of Hepatology, 14, 86-88.

[33] Giordanino, C., Bugianesi, E., Smedile, A., Ciancio, A., Abate, M.L., Olivero, A., et al. (2008) Incidence of Type 2 Diabetes Mellitus and Glucose Abnormalities in Patients with Chronic Hepatitis C Infection by Response to Treatment: Results of a Cohort Study. American Journal of Gastroenterology, 103, 2481-2487. http://dx.doi.org/10.1111/j.1572-0241.2008.02002.x

[34] Wlazlo, N., Beijers, B.H., Schoon, E.J., Sauerwein, H.P., Stehouwer, C.D. and Bravenboer, B. (2010) High Prevalence of Diabetes Mellitus in Patients with Liver Cirrhosis. Diabetic Medicine, 27, 1308-1311. http://dx.doi.org/10.1111/j.1464-5491.2010.03093.x

[35] Singal, A. and Ayoola, A. (2008) Prevalence and Factors Affecting Occurrence of Type 2 Diabetes Mellitus in Saudi Patients with Chronic Liver Disease. Saudi Journal of Gastroenterology, 14, 118-121. http://dx.doi.org/10.4103/1319-3767.41729

[36] Costantini, S., Capone, F., Guerriero, E., Marfella, R., Sorice, A., Maio, P., et al. (2012) Cytokine Profile of Patients with Type 2 Diabetes and/or Chronic Hepatitis C Infection. PLoS ONE, 7, e39486. http://dx.doi.org/10.1371/journal.pone.0039486

[37] Stepanova, M., Lam, B., Younossi, Y., Srishord, M.K. and Younossi, Z.M. (2012) Association of Hepatitis C with Insulin Resistance and Type 2 Diabetes in US General Population: The Impact of the Epidemic of Obesity. Journal of Viral Hepatitis, 19, 341-345. http://dx.doi.org/10.1111/j.1365-2893.2011.01554.x 
[38] Wild, S., Roglic, G., Green, A., Sicree, R. and King, H. (2004) Global Prevalence of Diabetes; Estimates for the Year 2000 and Projection for 2030. Diabetes Care, 27, 1047-1053. http://dx.doi.org/10.2337/diacare.27.5.1047

[39] Huang, J.F., Dai, C.Y., Hwang, S.J., Ho, C.K., Hsiao, P.J., Hsieh, M.Y., et al. (2007) Hepatitis C Viremia Increases the Association with Type 2 Diabetes Mellitus in a Hepatitis B and C Endemic Area: An Epidemiological Link with Virological Implication. American Journal of Gastroenterology, 102, 1237-1243. http://dx.doi.org/10.1111/j.1572-0241.2007.01181.x

[40] Rajesh, N.G. and Sadiq, K.A. (2012) Seroprevalence and Risk Factors for Hepatitis C Virus Infection among General Population in Central Region of Yemen. Hepatitis Research and Treatment, 2012, Article ID: 689726.

[41] Wang, C.S., Wang, S.T. and Chang, T.T. (2002) Smoking and Alanine Transferase Levels in Hepatitis C: Implications for Prevention of HCV Progression. Archives of Internal Medicine, 162, 811-815. http://dx.doi.org/10.1001/archinte.162.7.811

[42] Eissa, N.A., Ghonaim, M., ElBanna, H., Bakr, A., Mostafa, M.S., Shoeib, S. and AbdelMoteleb, T. (2003) HCV-Related Chronic Liver Disease Co-Factors That Determine the Severity and Prognosis. Egyptian Journal of Medical Microbiology, 12, 123-133.

[43] Alavian, S.M., Hajarizadeh, B., Nematizadeh, F. and Larijini, B. (2004) Prevalence and Determinants of Diabetes Mellitus among Iranian Patients with Chronic Liver Disease. BMC Endocrine Disorders, 4, 4. http://dx.doi.org/10.1186/1472-6823-4-4

[44] Marchesini, G., Ronchi, M., Forlani, G., Bugianesi, E., Bianchi, G., Fabbri, A., et al. (1999) Cardiovascular Disease in Cirrhosis. American Journal of Gastroenterology, 94, 655-662.

[45] Ndako, J.A., Echeonwu, G.O., Shidali, N.N., Bichi, I.A., Paul, G.A., Onovoh, E., et al. (2009) Occurrence of Hepatitis C Virus Infection in Type 2 Diabetic Patients Attending Plateau State Specialist Hospital Jos Nigeria. Virology Journal, 6, 98. http://dx.doi.org/10.1186/1743-422X-6-98

[46] Zimmet, P., Alberti, K.G. and Shaw, J. (2001) Global and Societal Implications of the Diabetes Epidemic. Nature, 414, 782-787. http://dx.doi.org/10.1038/414782a

[47] Lonardo, A., Adinolfi, L.E., Loria, P., Carulli, N., Ruggiero, G. and Day, C.P. (2004) Steatosis and Hepatitis C Virus: Mechanisms and Significance for Hepatic and Extrahepatic Disease. Gastroenterology, 126, 586-597. http://dx.doi.org/10.1053/j.gastro.2003.11.020

[48] Harris, M.I. (2005) Elevated Liver Function Tests in Type II DM. Clinical Diabetes, 23, 115-119. http://dx.doi.org/10.2337/diaclin.23.3.115

[49] Jadoon, N.A., Shahzad, M.A., Yaqoob, R., Hussain, M. and Ali, N. (2010) Seroprevalence of Hepatitis C in Type 2 Diabetes: Evidence for a Positive Association. Virology Journal, 7, 304. 